\title{
Synthesis of Carboxymethylpullulan-Peptide-Doxorubicin Conjugates and Their Properties
}

\author{
Hideo Nogusa, ${ }^{*, 1 a}$ Toshiro Yano, ${ }^{1 b)}$ Satoshi Okuno, ${ }^{1 b)}$ Hiroshi Hamana, ${ }^{1 a)}$ and \\ Kazuhiro INOUE ${ }^{1 c)}$ \\ Drug Delivery System Institute, Ltd., 2669 Yamazaki, Noda-shi, Chiba 278, Japan. \\ Received June 22, 1995; accepted July 10, 1995
}

The amino group of doxorubicin (DXR) was found to be bound to the carboxyl group of carboxymethylpullulan (CMPul) either directly or through tetrapeptide spacers, including Gly-Gly-Phe-Gly, Gly-Phe-Gly-Gly and Gly-Gly-Gly-Gly. These conjugates had DXR contents of $6.1-7.1 \%$, with the degree of substitution of carboxymethyl groups being 0.6 per sugar moiety. These conjugates associate in phosphate-buffered saline (PBS) (pH 7.4), forming micelles with hydrophobic DXR inside and hydrophilic CMPul on the outside. The amounts of DXR released from the conjugates in the presence of rat liver lysosomal enzymes were determined by HPLC. The rate of the drug release differed among the conjugates tested. CMPul-DXR conjugate bound through Gly-Gly-Phe-Gly released 35\% of its DXR over $24 \mathrm{~h}$. On the other hand, CMPul-DXR conjugate without spacer released no free DXR. The antitumor effect of each conjugate in rats bearing Walker 256 was studied by monitoring the tumor weights after a single intravenous injection. Compared with DXR, CMPul-DXR conjugates bound through Gly-Gly-Phe-Gly and Gly-Phe-Gly-Gly spacers significantly suppressed the tumor growth, while CMPul-DXR conjugate bound through Gly-Gly-Gly-Gly showed less antitumor effect than DXR. CMPul-DXR conjugate without spacer showed no in vivo antitumor effect even at a dose equivalent to as much as $20 \mathrm{mg} / \mathrm{kg}$ of DXR.

Key words doxorubicin; peptide spacer; carboxymethylpullulan; polymeric drug

In treating malignant tumors, chemotherapy plays an important role, as well as surgery and radiation therapy. Doxorubicin (DXR), an anthracycline antibiotic, is one of the most widely used drugs in cancer chemotherapy. However, its clinical usefulness is limited by side effects, such as suppression of bone marrow function and cardiotoxicity. In recent years, many attempts have been made to improve the therapeutic index of DXR or daunorubicin (DNR), an analog of DXR, by using various drug delivery systems. One approach has been conjugation of the drug with macromolecular carriers, such as albumin, ${ }^{2)}$ immunogloblin, ${ }^{3)}$ synthetic polymer, ${ }^{4,5)}$ and poly-amino acid, ${ }^{6,7)}$ as well as polysaccharides, ${ }^{8-11)}$ since macromolecules have a wide variety of characteristics and functions.

Pullulan, an $\alpha$-1,6-linked linear polymer of maltotriose, has many advantages as a macromolecular drug carrier, including high water solubility, multiple hydroxyl groups that can readily be modified chemically, lack of immunogenicity, and usefulness as a plasma expander. ${ }^{12)}$ Takakura et al. ${ }^{13)}$ reported that carboxymethyldextran with a molecular size above $70 \mathrm{kDa}$ was retained in blood circulation and accumulated in the tumor. Therefore, pullulan is expected to have similar properties when it is carboxymethylated. Furthermore, drug release can be controlled by selection of a drug-carrier linkage which would be stable in the bloodstream, but degraded in or near the tumor cells. The length and sequence of the peptide spacer can regulate the rate of drug release. For example, Trouet et al. ${ }^{2)}$ showed that succinylalbumin-DNR conjugate bound through Ala-Leu-Ala-Leu or Leu-Ala-Leu was much more active against L1210 leukaemia in mice than DNR or the conjugate bound through spacers smaller than dipeptide. Duncan et al. ${ }^{4)}$ reported that the $N$-(2-hydroxypropyl)methacrylamide (HPMA)-DXR conjugate bound through biodegradable

* To whom correspondence should be addressed.
Gly-Phe-Leu-Gly was more active against mice bearing L1210 than the conjugate bound through non-degradable Gly-Gly. Considerable improvement in the antitumor activity of macromolecule-peptide-drug conjugates has been attained. However, little is known about their efficacy against solid tumors by systemic administration at low dose.

In this paper, we report the synthesis and properties of CMPul-DXR conjugates bound either directly or through tetrapeptide spacers, including Gly-Gly-Phe-Gly, GlyPhe-Gly-Gly or Gly-Gly-Gly-Gly. We also compared the in vivo antitumor effect of these conjugates with that of free DXR.

\section{Results and Discussion}

Synthesis The peptide derivatives of DXR $(\mathbf{6 a}-\mathbf{c})$ were prepared according to Masquelier et al. ${ }^{14)}$ with slight modifications. $N$-Triphenylmethyl (trityl) tetrapeptides $(\mathbf{4 a}-\mathbf{c})$, which were prepared by debenzylation of $N$-trityl $O$-benzyl tetrapeptides $(\mathbf{3 a}-\mathbf{c})$ via catalytic transfer hydrogenolysis, were condensed with DXR in the presence of dicyclohexylcarbodiimide (DCC) and $N$-hydroxysuccinimide (HOSu) to obtain $N$-trityl aminoacyl derivatives $(\mathbf{5 a}-\mathbf{c})$. The $N$-trityl groups of $\mathbf{5 a}-\mathbf{c}$ were smoothly removed by treatment with $75 \% \mathrm{AcOH}$ for $1 \mathrm{~h}$ at $25^{\circ} \mathrm{C}$. The acetate salts of peptidyl DXR were converted to their hydrochloride salts $(\mathbf{6 a -}-\mathbf{c})$.

CMPul (8) could be isolated as its sodium salt by treatment of pullulan (7) (molecular weight, $150 \mathrm{kDa}$ ) with chloroacetic acid in alkaline solution. The degree of substitution of the carboxymethyl group was 0.6 per glucose moiety. Next, $\mathbf{6 a}-\mathbf{c}$ or DXR was conjugated with CMPul in the presence of 2-ethoxy-1-ethoxycarbonyl-1,2dihydroquinoline (EEDQ) in a solution of $N, N$-dimethylformamide (DMF)- $\mathrm{H}_{2} \mathrm{O}(1: 1)$ to afford the conjugates (C) 1995 Pharmaceutical Society of Japan 

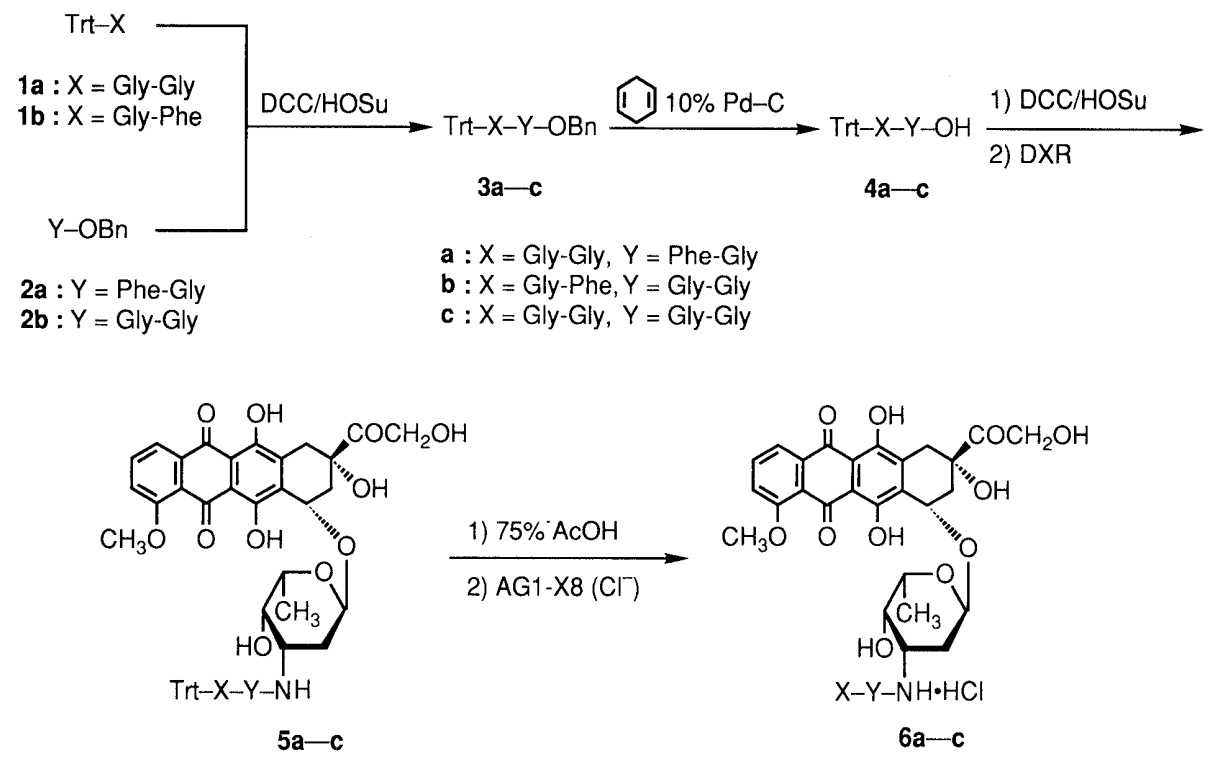

Chart 1
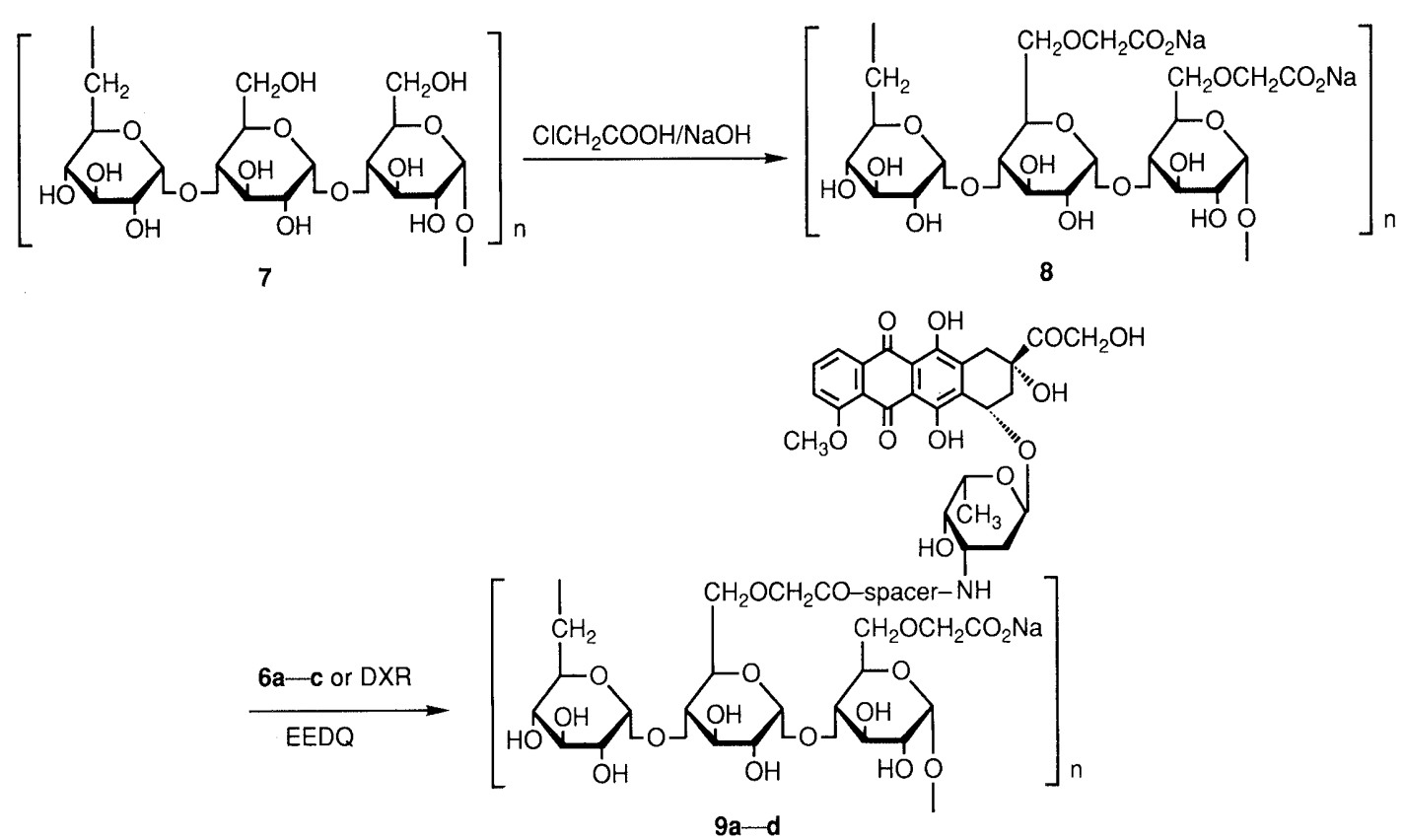

Chart 2

(9a-d). HPLC with detection of 9a at $480 \mathrm{~nm}$ (anthracycline ring), as shown in Fig. 1, confirmed that DXR was bound to the carrier. The possibility of an ester linkage via the C-14 hydroxyl group of DXR is considered to be small in this case, because no cross-linking product between the hydroxyl group and the carboxyl group of CMPul was detected, as shown in Fig. 1. However, the exact position of carboxymethylation in pullulan or amide formation between the carboxyl groups of CMPul and amino groups of $\mathbf{6 a}-\mathbf{c}$ or DXR could not be determined. Chart 2 shows a typical example. The DXR content of CMPul-DXR conjugates was determined by measuring the absorbance at $480 \mathrm{~nm}$ (Fig. 2). CMPul-DXR conjugates had DXR contents of $6.1-7.1 \%$, as shown in Table 1 .

In Vitro Stability in Dulbecco's Phosphate-Buffered Saline (PBS) The change in absorbance at $480 \mathrm{~nm}$ was monitored for DXR, a mixture of CMPul and DXR, and 9a-d in PBS (pH 7.4) at $37^{\circ} \mathrm{C}$, in order to examine the stability of DXR molecules. Absorbance of DXR after incubation for $96 \mathrm{~h}$ fell to $70 \%$ of the initial level. A mixture of DXR and CMPul showed slightly better stability. On the other hand, $9 a-d$ retained more than $98 \%$ of the initial absorbance after $96 \mathrm{~h}$ incubation (data shown only for 9a and 9d). HPLC monitoring revealed no DXR release from any of the conjugates (data not shown). The stability of the CMPul-DXR conjugates in PBS was presumably due to the shielding of DXR from hydroxyl ions by CMPul.

Fluorescence Measurements The fluorescence of DXR, 9a and 9d in PBS or PBS plus sodium dodecyl sulfate (SDS) was measured for DXR concentrations from $1.2 \times$ $10^{-7}$ to $1.0 \times 10^{-3} \mathrm{M}$. DXR showed 2.2-fold quenching of the fluorescence intensity in PBS at $6.2 \times 10^{-4} \mathrm{M}$ when compared with the intensity in $0.2 \%(\mathrm{w} / \mathrm{v})$ SDS. This 

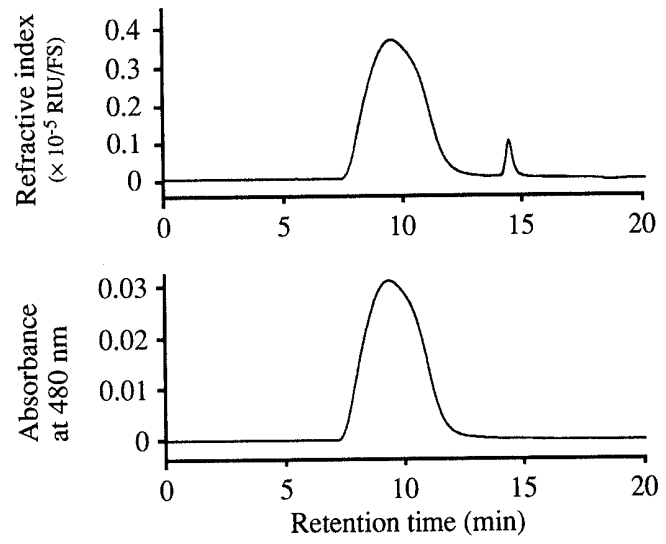

Fig. 1. HPLC Chromatogram of CMPul-Gly-Gly-Phe-Gly-DXR (9a)

Chromatographic conditions : column, TSKgel G4000 $\mathrm{PW}_{\mathrm{XL}}(300 \mathrm{~mm} \times 7.8 \mathrm{~mm}$ i.d.); eluent, $0.1 \mathrm{M} \mathrm{NaCl}$; flow rate, $0.8 \mathrm{ml} / \mathrm{min}$; column temperature, $40^{\circ} \mathrm{C}$; sample volume, $10 \mu \mathrm{l}(5 \mathrm{mg} / \mathrm{ml})$.

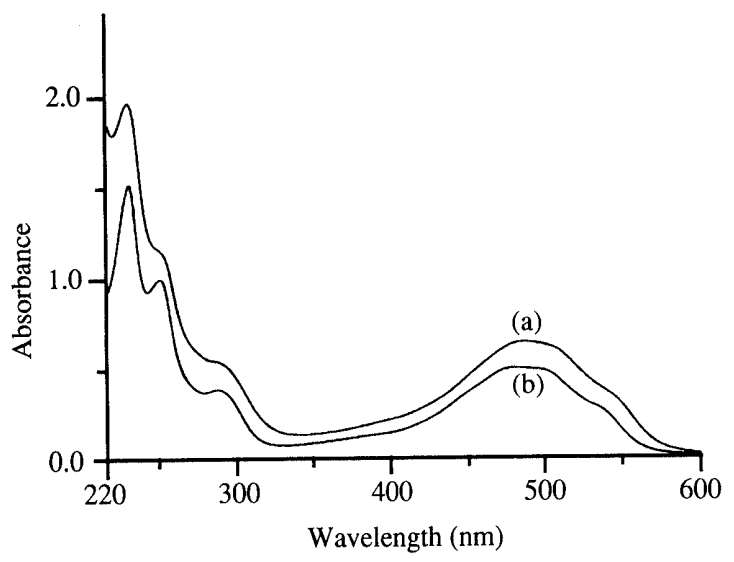

Fig. 2. UV-VIS Spectrum of CMPul-Gly-Gly-Phe-Gly-DXR (9a) and DXR in PBS

(a) $9 \mathrm{a}\left(\mathrm{DXR}=5.4 \times 10^{-5} \mathrm{M}\right)$; (b) DXR $\left(\mathrm{DXR}=4.7 \times 10^{-5} \mathrm{M}\right)$.

Table 1. DXR Content of CMPul-DXR Conjugates

\begin{tabular}{ccc}
\hline \hline Run & Spacer & DXR Content $^{a)}(\%)$ \\
\hline 9a & Gly-Gly-Phe-Gly & 6.1 \\
9b & Gly-Phe-Gly-Gly & 6.1 \\
9c & Gly-Gly-Gly-Gly & 6.9 \\
9d & None & 7.1
\end{tabular}

a) The amount of bound DXR was estimated spectrophotometrically at $480 \mathrm{~nm}$ in PBS.

quenching resulted from the dimerization of DXR through hydrophobic interactions in aqueous solution, ${ }^{15)}$ with the interaction being destroyed by addition of SDS. Quenching of the fluorescence intensity of $9 \mathrm{a}$ and $9 \mathrm{~d}$ was 7.6 - and 6.5-fold, respectively, in PBS at $6.2 \times 10^{-4} \mathrm{M}$, as compared with that of DXR. Furthermore, quenching of the intensity of 9a was not cancelled completely by addition of $5 \%$ $(\mathrm{w} / \mathrm{v})$ SDS. Ulbrich et al. ${ }^{16)}$ showed that the conjugate of HPMA- $p$-nitroaniline bound through oligopeptide spacer forms micelles in water with $p$-nitroaniline inside and HPMA on the outside. CMPul-DXR conjugates are considered to form micelles in PBS with DXR inside and CMPul on the outside, and the DXR molecules are tightly

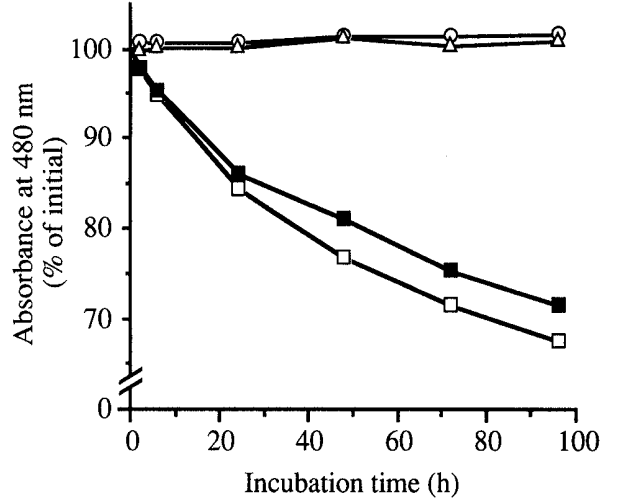

Fig. 3. Stability of DXR, DXR Plus CMPul, CMPul-Gly-Phe-GlyGly-DXR (9a) and CMPul-DXR (9d) in PBS at $37^{\circ} \mathrm{C}$ in the Dark, Estimated from the Absorbance at $480 \mathrm{~nm}$

$\square$, DXR (DXR $\left.=2.7 \times 10^{-5} \mathrm{M}\right) ; \mathbf{\square}$, DXR (DXR $\left.=2.7 \times 10^{-5} \mathrm{M}\right)$ plus CMPul $(0.3 \mathrm{mg} / \mathrm{ml}) ; \mathrm{O}, 9 \mathrm{a}\left(\mathrm{DXR}=3.3 \times 10^{-5} \mathrm{M}\right) ; \bullet, 9 \mathrm{~d}\left(\mathrm{DXR}=3.1 \times 10^{-5} \mathrm{M}\right)$.

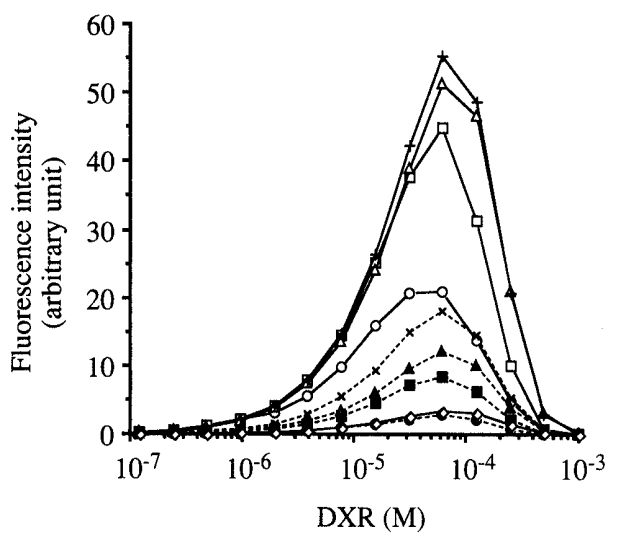

Fig. 4. Plot of Fluorescence Intensity of DXR, CMPul-Gly-Gly-PheGly-DXR (9a) and CMPul-DXR (9d) in PBS

O, DXR; $\square$, DXR plus $0.2 \%$ (w/v) SDS; $\triangle$, DXR plus $1 \%$ (w/v) SDS; + , DXR plus $5 \%(\mathrm{w} / \mathrm{v})$ SDS;, $9 a ; \square, 9 a$ plus $0.2 \%(\mathrm{w} / \mathrm{v})$ SDS; $\boldsymbol{\Lambda}$, 9a plus $1 \%$ $(w / v)$ SDS; $\times$, 9a plus $5 \%(w / v)$ SDS; $\diamond, 9 d$.

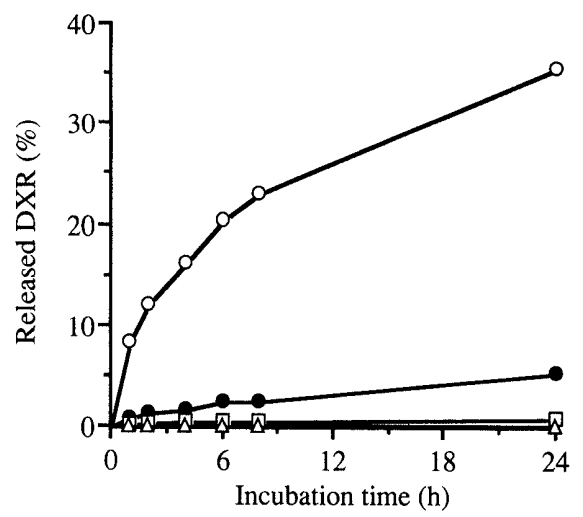

Fig. 5. Digestion of CMPul-DXR Conjugates by Lysosomal Enzymes in Vitro

The Conjugates (DXR $=1.8 \times 10^{-5} \mathrm{M}$ ) were incubated at $37^{\circ} \mathrm{C}$ in $0.2 \mathrm{M}$ citrate buffer $(\mathrm{pH} 5.5)$, containing EDTA $(1 \mathrm{~mm}), 0.2 \%$ Triton $\mathrm{X}-100$ and reduced glutathione $(5 \mathrm{mM})$ in the presence of lysosomal enzymes from rat liver. After various times, aliquots were taken and DXR released was determined by HPLC. $0,9 \mathrm{a} ; \bullet, 9 \mathrm{~b} ; \square, 9 \mathrm{c} ; \triangle, 9 \mathrm{~d}$.

packed inside a hydrophobic core of the micelles.

In Vitro Digestion by Lysosomal Enzymes In order to examine the sensitivity of $\mathbf{9 a}-\mathbf{d}$ to hydrolysis by lysosomal enzymes, they were incubated at $\mathrm{pH} 5.5$ in the presence 
Table 2. Antitumor Effects of CMPul-DXR Conjugates and DXR on Rats Bearing Walker 256 Tumor

\begin{tabular}{ccc}
\hline Run & Dose $(\mathrm{mg} / \mathrm{kg})^{a)}$ & $\mathrm{T} / \mathrm{C}(\%)^{b)}$ \\
\hline DXR & 0.8 & $55.6 \pm 3.6$ \\
& 5.0 & $13.7 \pm 1.6$ \\
9a & 0.8 & $11.0 \pm 3.2$ \\
9b & 0.8 & $24.1 \pm 3.4$ \\
9c & 0.8 & $92.1 \pm 6.6$ \\
9d & 5.0 & $99.7 \pm 4.9$ \\
& 20.0 & $85.3 \pm 7.8$
\end{tabular}

The drugs were given intravenously $3 \mathrm{~d}$ after i.m. inoculation of Walker carcinosarcoma 256 into Wistar rats. The tumor weight was measured $7 \mathrm{~d}$ after the tumor inoculation. a) The dose is expressed as DXR content. b) $\mathrm{T} / \mathrm{C}(\%)=$ (tumor weight of the treatment group/that of the untreated group) $\times 100$. Means \pm S.D. of five rats per group.

of lysosomal enzymes derived from rat liver. ${ }^{17}$ The kinetics of hydrolysis of these conjugates into DXR, as determined by HPLC, are illustrated in Fig. 5. The release of DXR by lysosomal enzymes acting on CMPul-DXR conjugates is affected by the presence and composition of the peptide spacer between drug and carrier. After $24 \mathrm{~h}$ incubation, $9 \mathbf{a}-\mathbf{c}$ released $35 \%, 5.4 \%$, and $0.9 \%$ of DXR, respectively, and no free DXR was detected in the case of 9d.

In Vivo Antitumor Effect The antitumor effects of each conjugate and DXR were tested by monitoring the tumor weights after a single intravenous administration in rats bearing Walker 256. At a dose of $0.8 \mathrm{mg} / \mathrm{kg}$ as DXR, T/C values of $9 \mathrm{a}-\mathbf{c}$ and DXR were about $11 \%, 24 \%, 92 \%$ and $56 \%$, respectively. Thus, $9 \mathrm{a}$ and $9 \mathrm{~b}$ showed a greater antitumor effect than DXR, while 9c showed a lesser antitumor effect than DXR. Compound 9d showed no in vivo antitumor effect even at the high dose of $20 \mathrm{mg} / \mathrm{kg}$. In addition, the present study showed that the in vivo antitumor effect was correlated with the rate of drug release in the presence of lysosomal enzymes in vitro.

Conjugates of DXR directly bound to polymer carriers, such as the poly(ethyleneglycol)-poly(aspartic acid) block copolymer $^{18)}$ or the copolymer of divinyl ether and maleic anhydride (DIVEMA), ${ }^{5)}$ were effective in vivo against tumor-bearing mice. Hirano et al. ${ }^{5)}$ showed DXR was released gradually from the conjugate of DIVEMA and DXR under physiological conditions at $\mathrm{pH}$ 7.2. DXR showed an antitumor effect on the surface of the cell, when attached to microspheres. ${ }^{19)}$ In this case, hydrolysis of the attached DXR may not have been necessary, since DXR can exert antitumor activity without entering the cells. However, 9d showed no in vivo antitumor effect at a high dose, and no release of DXR from 9d in PBS or in the presence of lysosomal enzymes was observed. Therefore, DXR released from CMPul-DXR conjugate may kill tumor cells by intercalation between the base pairs of DNA. ${ }^{20)}$ Although the action mechanism of CMPul-DXR conjugates is still unknown, when they are bound through appropriate tetrapeptide spacers, they showed high in vivo antitumor activity against solid tumor even at a low dose, in comparison with DXR.

\section{Experimental}

Melting points were measured on a Yanaco melting-point apparatus without correction. Column chromatography was performed on columns of silica gel (Merck, $230-400$ mesh). Optical rotations were measured in $\mathrm{CHCl}_{3}$ or $\mathrm{MeOH}$ with a Perkin-Elmer Model 141 polarimeter. ${ }^{1} \mathrm{H}$-NMR spectra were recorded with a Varian VXR-500 FT NMR spectrometer for $\mathrm{CDCl}_{3}$ or $\mathrm{CD}_{3} \mathrm{OD}$ solutions. $\delta_{\mathrm{H}}$ values are expressed in ppm downfield from the signal for internal $\mathrm{Me}_{4} \mathrm{Si}$. High-resolution liquid secondary-ion mass spectra (HL-SI-MS) were measured with a Hitachi M-90 mass spectrometer, with $\mathrm{Cs}^{+}$as the primary ion, using $m$-nitrobenzyl alcohol as the matrix and polyethylene glycol 600 with or without $\mathrm{KI}$ or $\mathrm{NaI}$ as an internal standard. Fluorescence was measured using a Shimadzu RF-5000 fluorescence spectrophotometer, with excitation at $470 \mathrm{~nm}$ and emission at $560 \mathrm{~nm}$. UV-VIS spectra were recorded with a Shimadzu UV-3100 spectrophotometer.

Trt-Gly-Gly (1a) Trityl chloride $(18.1 \mathrm{~g}, 64.9 \mathrm{mmol})$ was added in twelve equal portions within $1 \mathrm{~h}$ to a solution of Gly-Gly $(6.60 \mathrm{~g}$, $50.0 \mathrm{mmol})$ in a mixture of $\mathrm{H}_{2} \mathrm{O}(20 \mathrm{ml}), 2$-propanol $(40 \mathrm{ml})$ and diethylamine $(15 \mathrm{ml})$. The reaction mixture was stirred for a further $1 \mathrm{~h}$, then $\mathrm{H}_{2} \mathrm{O}(150 \mathrm{ml})$ was added. The resulting colorless precipitate was washed with $\mathrm{H}_{2} \mathrm{O}$. Acidification of the combined filtrate and washing solution with $\mathrm{AcOH}$ and drying of the precipitate in vacuo gave 1a (15.3 g, $82 \%$ ). mp $179-180^{\circ} \mathrm{C}$ (lit. ${ }^{21)} 180^{\circ} \mathrm{C}$ ). ${ }^{1} \mathrm{H}-\mathrm{NMR}\left(\mathrm{CD}_{3} \mathrm{OD}\right) \delta: 2.92(\mathrm{~s}$, $2 \mathrm{H}$, Trt-Gly- $\alpha \mathrm{CH}_{2}$ ), 3.97 (s, $2 \mathrm{H}$, Gly- $\alpha \mathrm{CH}_{2}$ ), 7.20-7.47 (m, 15H, aromatic $\mathrm{H}$ ).

Trt-Gly-Phe (1b) Gly--Phe $(1.10 \mathrm{~g}, 5.00 \mathrm{mmol})$ was dissolved in a mixture of $\mathrm{H}_{2} \mathrm{O}(2 \mathrm{ml}), 2$-propanol $(4 \mathrm{ml})$ and diethylamine $(1.5 \mathrm{ml})$, and the reaction mixture was treated with trityl chloride $(1.81 \mathrm{~g}, 6.49 \mathrm{mmol})$ as described for $\mathbf{1 a}$, to afford $\mathbf{1 b}(1.79 \mathrm{~g}, 77 \%)$. mp $237-238^{\circ} \mathrm{C} \cdot[\alpha]_{\mathrm{D}}^{25}$ $+33.0(c=1.0, \mathrm{MeOH}) .{ }^{1} \mathrm{H}-\mathrm{NMR}\left(\mathrm{CD}_{3} \mathrm{OD}\right) \delta: 2.75(\mathrm{~d}, 1 \mathrm{H}, J=17.0 \mathrm{~Hz}$, Gly- $\left.\alpha \mathrm{CH}_{\mathrm{a}}\right), 2.84\left(\mathrm{~d}, 1 \mathrm{H}, J=17.0 \mathrm{~Hz}, \mathrm{Gly}-\alpha \mathrm{CH}_{\mathrm{b}}\right), 3.21\left(\mathrm{~m}, 2 \mathrm{H}, \mathrm{Phe}-\beta \mathrm{CH}_{2}\right)$, $4.71(\mathrm{t}, 1 \mathrm{H}, J=5.2 \mathrm{~Hz}$, Phe- $\alpha \mathrm{CH}), 7.18-7.34(\mathrm{~m}, 20 \mathrm{H}$, aromatic $\mathrm{H})$. Anal. Calcd for $\mathrm{C}_{30} \mathrm{H}_{28} \mathrm{~N}_{2} \mathrm{O}_{3} \cdot 0.2 \mathrm{H}_{2} \mathrm{O}: \mathrm{C}, 76.97 ; \mathrm{H}, 6.11 ; \mathrm{N}, 5.98$. Found: C, 77.07; H, 6.43; N, 6.09.

Phe-Gly-OBn (2a) A mixture of Phe-Gly-OH $\cdot \mathrm{H}_{2} \mathrm{O}(25.0 \mathrm{~g}, 104$ mmol), p-toluenesulfonic acid monohydrate $(20.9 \mathrm{~g}, 110 \mathrm{mmol})$ and benzyl alcohol $(25 \mathrm{ml})$ in toluene $(200 \mathrm{ml})$ was heated at reflux for $5 \mathrm{~h}$ in a Dean-Stark apparatus. The solution was concentrated, followed by the addition of ethyl ether, giving the $p$-toluenesulfonate of $\mathbf{2 a}$ as colorless crystals $(48.1 \mathrm{~g}, 95 \%)$. mp $135-137^{\circ} \mathrm{C} .[\alpha]_{\mathrm{D}}^{25}+17.8^{\circ}(c=1.0, \mathrm{MeOH})$ ${ }^{1} \mathrm{H}-\mathrm{NMR}\left(\mathrm{CD}_{3} \mathrm{OD}\right) \delta: 2.36(\mathrm{~s}, 3 \mathrm{H}, \mathrm{Phe}-\mathrm{Me}), 2.99(\mathrm{dd}, 1 \mathrm{H}, J=14.2$, $8.5 \mathrm{~Hz}$, Phe- $\left.\beta \mathrm{CH}_{\mathrm{a}}\right), 3.24$ (dd, $1 \mathrm{H}, J=14.2,5.9 \mathrm{~Hz}$, Phe $\left.-\beta \mathrm{CH}_{\mathrm{b}}\right), 4.02(\mathrm{~d}$, $\left.1 \mathrm{H}, J=17.8 \mathrm{~Hz}, \mathrm{Gly}-\alpha \mathrm{CH}_{\mathrm{a}}\right), 4.06\left(\mathrm{~d}, 1 \mathrm{H}, J=17.8 \mathrm{~Hz}, \mathrm{Gly}-\alpha \mathrm{CH}_{\mathrm{b}}\right), 4.11$ (dd, $1 \mathrm{H}, \mathrm{Phe}-\alpha \mathrm{CH}, J=8.5,5.9 \mathrm{~Hz}), 5.11\left(\mathrm{~d}, 1 \mathrm{H}, J=12.2 \mathrm{~Hz}, \mathrm{O}-\mathrm{CH}_{\mathrm{a}}-\mathrm{Phe}\right)$, $5.17\left(\mathrm{~d}, 1 \mathrm{H}, J=12.2 \mathrm{~Hz}, \mathrm{O}-\mathrm{CH}_{\mathrm{b}}-\mathrm{Phe}\right), 7.22(\mathrm{~d}, 2 \mathrm{H}, J=8.1 \mathrm{~Hz}$, aromatic $\mathrm{H}), 7.28-7.38(\mathrm{~m}, 5 \mathrm{H}$, aromatic $\mathrm{H}), 7.71(\mathrm{~d}, 2 \mathrm{H}, J=8.1 \mathrm{~Hz}$, aromatic H). Anal. Calcd for $\mathrm{C}_{25} \mathrm{H}_{28} \mathrm{~N}_{2} \mathrm{O}_{6} \mathrm{~S} \cdot 0.2 \mathrm{H}_{2} \mathrm{O}: \mathrm{C}, 61.51 ; \mathrm{H}, 5.82 ; \mathrm{N}, 5.74$. Found: C, 61.41; H, 5.79; N, 5.64.

Trt-Gly-Gly-Phe-Gly-OBn (3a) A stirred solution of $1 \mathrm{a}(1.54 \mathrm{~g}$, $4.10 \mathrm{mmol})$ and HOSu $(0.52 \mathrm{~g}, 4.50 \mathrm{mmol})$ in dry DMF $(5 \mathrm{ml})$ at $4{ }^{\circ} \mathrm{C}$ was treated with DCC $(0.928 \mathrm{~g}, 4.50 \mathrm{mmol})$. After $2 \mathrm{~h}$, a solution of the p-toluenesulfonate of 2a $(1.99 \mathrm{~g}, 4.10 \mathrm{mmol})$ and $N$-methylmorpholine (NMM) $(0.414 \mathrm{~g}, 4.10 \mathrm{mmol})$ in dry DMF $(10 \mathrm{ml})$ was added and stirring was continued at $4{ }^{\circ} \mathrm{C}$ for $15 \mathrm{~h}$. The precipitate was removed by filtration and the filtrate was concentrated. The residue was partitioned between $\mathrm{CHCl}_{3}$ and $\mathrm{H}_{2} \mathrm{O}$. The organic phase was successively washed with $5 \%$ $\mathrm{NaHCO}_{3}$ and $\mathrm{H}_{2} \mathrm{O}$, dried $\left(\mathrm{Na}_{2} \mathrm{SO}_{4}\right)$, and concentrated. Chromatography of the residue on a column of silica gel with $\mathrm{CHCl}_{3}-\mathrm{MeOH}(20: 1)$ gave 3a $(1.96 \mathrm{~g}, 72 \%) . \operatorname{mp} 142-146^{\circ} \mathrm{C} .[\alpha]_{\mathrm{D}}^{25}-13.3^{\circ}\left(c=1.0, \mathrm{CHCl}_{3}\right)$. ${ }^{1} \mathrm{H}-\mathrm{NMR}\left(\mathrm{CDCl}_{3}\right) \delta: 2.90\left(\mathrm{dd}, J=14.0,8.5 \mathrm{~Hz}, \mathrm{Phe}-\beta \mathrm{CH}_{\mathrm{a}}\right), 2.91-3.02$ $\left(\mathrm{m}, 2 \mathrm{H}, \mathrm{Trt}-\mathrm{Gly}-\alpha \mathrm{CH}_{2}\right), 3.22\left(\mathrm{dd}, 2 \mathrm{H}, J=14.0,5.9 \mathrm{~Hz}\right.$, Phe- $\left.\beta \mathrm{CH}_{\mathrm{b}}\right)$ $3.88-4.02\left(\mathrm{~m}, 4 \mathrm{H}, \mathrm{Gly}-\alpha \mathrm{CH}_{2} \times 2\right), 4.50(\mathrm{~m}, 1 \mathrm{H}, \mathrm{Phe}-\alpha \mathrm{CH}), 5.01(\mathrm{~s}, 2 \mathrm{H}$, $\left.\mathrm{O}-\mathrm{CH}_{2}-\mathrm{Phe}\right), 7.19-7.30(\mathrm{~m}, 25 \mathrm{H}$, aromatic $\mathrm{H})$. Anal. Calcd for $\mathrm{C}_{41} \mathrm{H}_{40} \mathrm{~N}_{4} \mathrm{O}_{5}: \mathrm{C}, 73.63 ; \mathrm{H}, 6.03 ; \mathrm{N}, 8.38$. Found: C, 73.53; H, 6.00; N, 8.48 .

Trt-Gly-Phe-Gly-Gly-OBn (3b) 1b $(2.32 \mathrm{~g}, 5.00 \mathrm{mmol})$ and $\mathbf{2 b}$, prepared from its $p$-toluenesulfonate ${ }^{22)}(1.97 \mathrm{~g}, 5.00 \mathrm{mmol})$ and NMM $(0.506 \mathrm{~g}, 5.00 \mathrm{mmol})$, were coupled as described for $\mathbf{3 a}$, and chromatography of the product on a column of silica gel with $\mathrm{CHCl}_{3}-\mathrm{MeOH}(20: 1)$ gave $3 \mathbf{b}(3.00 \mathrm{~g}, 90 \%)$. mp $180-183^{\circ} \mathrm{C}$. $[\alpha]_{\mathrm{D}}^{2.5}$ $+28.2^{\circ}\left(c=1.0, \mathrm{CHCl}_{3}\right) .{ }^{1} \mathrm{H}-\mathrm{NMR}\left(\mathrm{CDCl}_{3}\right) \delta: 2.89(\mathrm{dd}, 1 \mathrm{H}, J=17.4$, $7.3 \mathrm{~Hz}$, Trt-Gly- $\left.\alpha \mathrm{CH}_{\mathrm{a}}\right), 2.90\left(\mathrm{dd}, 1 \mathrm{H}, J=14.0,8.5 \mathrm{~Hz}, \mathrm{Phe}-\beta \mathrm{CH}_{\mathrm{a}}\right), 2.98$ $\left(\mathrm{dd}, 1 \mathrm{H}, J=17.4,9.5 \mathrm{~Hz}\right.$, Trt-Gly- $\left.\alpha \mathrm{CH}_{\mathrm{b}}\right), 3.22(\mathrm{dd}, 1 \mathrm{H}, J=14.0,5.9 \mathrm{~Hz}$, Phe $\left.-\beta \mathrm{CH}_{\mathrm{b}}\right), 3.86-4.02\left(\mathrm{~m}, 4 \mathrm{H}\right.$, Gly- $\left.\alpha \mathrm{CH}_{2} \times 2\right), 4.54(\mathrm{~m}, 1 \mathrm{H}$, Phe- $\alpha \mathrm{CH})$, $5.01\left(\mathrm{~s}, 2 \mathrm{H}, \mathrm{O}-\mathrm{CH}_{2}-\mathrm{Phe}\right), 7.16-7.35(\mathrm{~m}, 25 \mathrm{H}$, aromatic $\mathrm{H})$. Anal. Calcd for $\mathrm{C}_{41} \mathrm{H}_{40} \mathrm{~N}_{4} \mathrm{O}_{5}: \mathrm{C}, 73.63 ; \mathrm{H}, 6.03 ; \mathrm{N}, 8.38$. Found: C, 73.59; H, 5.98; 
N, 8.44 .

Trt-Gly-Gly-Gly-Gly-OBn (3c) $\mathbf{1 a}(1.87 \mathrm{~g}, 5.00 \mathrm{mmol})$ and $\mathbf{2 b}$, prepared from its $p$-toluenesulfonate ${ }^{22)}(1.97 \mathrm{~g}, 5.00 \mathrm{mmol})$ and NMM $(0.506 \mathrm{~g}, 5.00 \mathrm{mmol})$, were coupled as described for $\mathbf{3 a}$, and chromatography of the product on a column of silica gel with $\mathrm{CHCl}_{3}-\mathrm{MeOH}$ (10: l) gave 3c $(1.75 \mathrm{~g}, 60 \%) . \mathrm{mp} 144-146^{\circ} \mathrm{C} .{ }^{1} \mathrm{H}-\mathrm{NMR}\left(\mathrm{CDCl}_{3}\right) \delta$ : 2.93 (s, 2H, Trt-Gly- $\alpha \mathrm{CH}_{2}$ ), 3.94 (s, 2H, Gly- $\alpha \mathrm{CH}_{2}$ ), 3.96 (s, $2 \mathrm{H}$, Gly- $\alpha \mathrm{CH}_{2}$ ), 4.00 (s, 2H, Gly- $\alpha \mathrm{CH}_{2}$ ), 5.14 (s, 2H, O-CH$\left.{ }_{2}-\mathrm{Phe}\right), 7.19$ $7.47(\mathrm{~m}, 20 \mathrm{H}$, aromatic $\mathrm{H})$. Anal. Calcd for $\mathrm{C}_{34} \mathrm{H}_{34} \mathrm{~N}_{4} \mathrm{O}_{5} \cdot 0.2 \mathrm{H}_{2} \mathrm{O}$ : C, 70.13; H, 5.95; N, 9.62. Found: C, 70.15; H, 5.99; N, 9.86.

Trt-Gly-Gly-Phe-Gly-OH (4a) A mixture of a solution of $3 \mathbf{a}(1.34 \mathrm{~g}$, $2.00 \mathrm{mmol})$ in DMF $(10 \mathrm{ml}), 10 \% \mathrm{Pd}-\mathrm{C}(0.150 \mathrm{~g})$ and 1,4-cyclohexadiene $(0.300 \mathrm{~g})$ was stirred for $30 \mathrm{~min}$ at room temperature. After removal of the catalyst by filtration, the filtrate was evaporated. The resulting mixture was applied to a column of silica gel with $\mathrm{CHCl}_{3}$ $\mathrm{MeOH}(7: 1)$ to afford $4 \mathrm{a}(1.13 \mathrm{~g}, 98 \%)$ mp $219-224^{\circ} \mathrm{C}$ (dec.). $[\alpha]_{\mathrm{D}}^{25}-14.3^{\circ}(c=1.0, \mathrm{MeOH}) .{ }^{1} \mathrm{H}-\mathrm{NMR}\left(\mathrm{CD}_{3} \mathrm{OD}\right) \delta: 2.90(\mathrm{~s}, 2 \mathrm{H}$, Trt-Gly- $\alpha \mathrm{CH}_{2}$ ), 2.90 (dd, $1 \mathrm{H}, J=14.2,8.8 \mathrm{~Hz}$, Phe- $\beta \mathrm{CH}_{\mathrm{a}}$ ), 3.23 (dd, $1 \mathrm{H}$, $J=14.2,5.6 \mathrm{~Hz}$, Phe- $\left.\beta \mathrm{CH}_{\mathrm{b}}\right), 3.64\left(\mathrm{~d}, 1 \mathrm{H}, J=17.5 \mathrm{~Hz}, \mathrm{Gly}-\alpha \mathrm{CH}_{\mathrm{a}}\right), 3.78$ $\left(\mathrm{d}, 1 \mathrm{H}, J=17.5 \mathrm{~Hz}, \mathrm{Gly}-\alpha \mathrm{CH}_{\mathrm{b}}\right), 3.80\left(\mathrm{~d}, 1 \mathrm{H}, J=16.5 \mathrm{~Hz}, \mathrm{Gly}-\alpha \mathrm{CH}_{\mathrm{a}}\right)$, $3.94\left(\mathrm{~d}, 1 \mathrm{H}, J=16.5 \mathrm{~Hz}, \mathrm{Gly}-\alpha \mathrm{CH}_{\mathrm{b}}\right), 4.64(\mathrm{dd}, 1 \mathrm{H}, J=8.8,5.6 \mathrm{~Hz}$, Phe- $\alpha \mathrm{CH}), \quad 7.18-7.45(\mathrm{~m}, 20 \mathrm{H}$, aromatic $\mathrm{H})$. Anal. Calcd for $\mathrm{C}_{34} \mathrm{H}_{34} \mathrm{~N}_{4} \mathrm{O}_{5} \cdot 2 \mathrm{H}_{2} \mathrm{O}: \mathrm{C}, 66.43 ; \mathrm{H}, 6.23 ; \mathrm{N}, 9.11$. Found: $\mathrm{C}, 66.58 ; \mathrm{H}$, $5.93 ; \mathrm{N}, 9.21$.

Trt-Gly-Phe-Gly-Gly-OH (4b) A solution of $3 \mathrm{~b}(2.01 \mathrm{~g}, 3.00 \mathrm{mmol})$ in DMF was hydrogenated according to the method described for $\mathbf{4 a}$, and chromatography of the product on a column of silica gel with $\mathrm{CHCl}_{3}-\mathrm{MeOH}(7: 1)$ gave $4 \mathrm{~b}(1.65 \mathrm{~g}, 95 \%)$. mp $213-215^{\circ} \mathrm{C}$ (dec.). $[\alpha]_{\mathrm{D}}^{25}$ $+18.2^{\circ}(c=1.0, \mathrm{MeOH}) .{ }^{1} \mathrm{H}-\mathrm{NMR}\left(\mathrm{CD}_{3} \mathrm{OD}\right) \delta: 2.75(\mathrm{~d}, 1 \mathrm{H}, J=16.8 \mathrm{~Hz}$, Trt-Gly- $\left.\alpha \mathrm{CH}_{\mathrm{a}}\right), 2.81\left(\mathrm{~d}, 1 \mathrm{H}, J=16.8 \mathrm{~Hz}\right.$, Trt- $\left.\mathrm{Gly}-\alpha \mathrm{CH}_{\mathrm{b}}\right), 2.99$ (dd, $1 \mathrm{H}$, $J=14.2,8.8 \mathrm{~Hz}$, Phe- $\left.\beta \mathrm{CH}_{\mathrm{a}}\right), 3.25\left(\mathrm{dd}, 1 \mathrm{H}, J=14.2,5.6 \mathrm{~Hz}\right.$, Phe- $\beta \mathrm{CH}_{\mathrm{b}}$ ), $3.84\left(\mathrm{~d}, 1 \mathrm{H}, J=17.2 \mathrm{~Hz}, \mathrm{Gly}-\alpha \mathrm{CH}_{\mathrm{a}}\right), 3.90\left(\mathrm{~s}, 2 \mathrm{H}, \mathrm{Gly}-\alpha \mathrm{CH}_{2}\right), 3.96(\mathrm{~d}$, $1 \mathrm{H}, J=17.2 \mathrm{~Hz}$, Gly- $\left.\alpha \mathrm{CH}_{\mathrm{b}}\right), 4.58(\mathrm{dd}, 1 \mathrm{H}, J=8.8,5.6 \mathrm{~Hz}$, Phe- $\alpha \mathrm{CH})$, $7.20-7.33$ (m, 20H, aromatic $\mathrm{H}$ ). $\mathrm{C}_{34} \mathrm{H}_{34} \mathrm{~N}_{4} \mathrm{O}_{5} \cdot 2 \mathrm{H}_{2} \mathrm{O}: \mathrm{C}, 66.43 ; \mathrm{H}$, $6.23 ; \mathrm{N}, 9.11$. Found: C, 66.28; H, 6.26; N, 8.93.

Trt-Gly-Gly-Gly-Gly-OH (4c) A solution of $3 \mathbf{c}(1.34 \mathrm{~g}, 2.00 \mathrm{mmol})$ in DMF was hydrogenated according to the method described for $\mathbf{4 a}$, and chromatography of the product on a column of silica gel with $\mathrm{CHCl}_{3}-\mathrm{MeOH}(5: 1)$ gave $\mathbf{4 c}(1.12 \mathrm{~g}, 97 \%)$. mp $190-191{ }^{\circ} \mathrm{C}$ (dec.) ${ }^{1} \mathrm{H}-\mathrm{NMR}\left(\mathrm{CD}_{3} \mathrm{OD}\right) \delta: 2.94$ (s, 2H, Trt-Gly- $\left.\alpha \mathrm{CH}_{2}\right), 3.93$ (s, 2H, Gly- $\alpha \mathrm{CH}_{2}$ ), 3.94 (s, $2 \mathrm{H}$, Gly- $\alpha \mathrm{CH}_{2}$ ), 3.97 (s, $2 \mathrm{H}, \mathrm{Gly}-\alpha \mathrm{CH}_{2}$ ), 7.19-7.48 (m, 15H, aromatic $\mathrm{H}$ ). Anal. Calcd for $\mathrm{C}_{27} \mathrm{H}_{28} \mathrm{~N}_{4} \mathrm{O}_{5} \cdot 0.6 \mathrm{H}_{2} \mathrm{O}: \mathrm{C}, 64.94$; H, 5.89; N, 11.22. Found: C, 64.90; H, 5.65; N, 11.42.

$\mathbf{3}^{\prime}-\mathbf{N}$-(Gly-Gly-Phe-Gly)-DXR $\cdot \mathbf{H C l}$ (6a) A stirred solution of $\mathbf{4 a}$ $(0.475 \mathrm{~g}, 0.820 \mathrm{mmol})$ and HOSu $(0.104 \mathrm{~g}, 0.900 \mathrm{mmol})$ in dry DMF $(4 \mathrm{ml})$ at $4^{\circ} \mathrm{C}$ was treated with $\mathrm{DCC}(0.186 \mathrm{~g}, 0.900 \mathrm{mmol})$. The reaction mixture was stirred for $2 \mathrm{~h}$. A solution of DXR, prepared from its hydrochloride $(0.476 \mathrm{~g}, 0.820 \mathrm{mmol})$ and NMM $(0.083 \mathrm{~g}, 0.820 \mathrm{mmol})$, in dry DMF $(10 \mathrm{ml})$ was poured into the solution and the whole was stirred at $4{ }^{\circ} \mathrm{C}$ for $10 \mathrm{~h}$. The precipitate was removed by filtration and the filtrate was concentrated. The residue was partitioned between $\mathrm{CHCl}_{3}$ and $\mathrm{H}_{2} \mathrm{O}$. The organic phase was dried $\left(\mathrm{Na}_{2} \mathrm{SO}_{4}\right)$ and concentrated, and chromatography of the residue on a column of silica gel with $\mathrm{CHCl}_{3}-\mathrm{MeOH}(20: 1)$ gave $5 \mathbf{a}(0.766 \mathrm{~g})$. A solution of $5 \mathbf{a}$ in $3 \mathrm{ml}$ of $75 \%$ $\mathrm{AcOH}$ was stirred for $1 \mathrm{~h}$ at room temperature, then $\mathrm{H}_{2} \mathrm{O}(50 \mathrm{ml})$ was poured into the solution, the precipitate was removed by filtration, and the filtrate was lyophilized. The product obtained was dissolved in $\mathrm{H}_{2} \mathrm{O}$ $(2 \mathrm{ml})$ and passed through an anion exchange resin column (AG 1-X8, $\mathrm{Cl}^{-}$form, BIO-RAD). The aqueous layer was extracted with $\mathrm{CHCl}_{3}$ and lyophilized to afford $6 \mathrm{a}(0.462 \mathrm{~g}, 63 \%)$. $[\alpha]_{\mathrm{D}}^{25}+219.1^{\circ}(c=0.1$, $\mathrm{MeOH}) .{ }^{1} \mathrm{H}-\mathrm{NMR}\left(\mathrm{CD}_{3} \mathrm{OD}\right) \delta: 1.28\left(\mathrm{~d}, 3 \mathrm{H}, J=6.6 \mathrm{~Hz}, \mathrm{H}-6{ }^{\prime}\right), 1.71(\mathrm{dd}$, $1 \mathrm{H}, J=12.7,4.6 \mathrm{~Hz}, \mathrm{H}-2_{\mathrm{b}}^{\prime}$ ), 1.98 (ddd, $1 \mathrm{H}, J=12.7,12.7,3.9 \mathrm{~Hz}, \mathrm{H}-2_{\mathrm{a}}^{\prime}$ ), $2.19\left(\mathrm{dd}, 1 \mathrm{H}, J=14.7,5.1 \mathrm{~Hz}, \mathrm{H}-8_{\mathrm{b}}\right), 2.38\left(\mathrm{~d}, 1 \mathrm{H}, J=14.7 \mathrm{~Hz}, \mathrm{H}-8_{\mathrm{a}}\right), 2.94$ $\left(\mathrm{dd}, 1 \mathrm{H}, J=13.9,8.4 \mathrm{~Hz}, \mathrm{Phe}-\beta \mathrm{CH}_{\mathrm{a}}\right), 3.00\left(\mathrm{~d}, 1 \mathrm{H}, J=18.6 \mathrm{~Hz}, \mathrm{H}-10_{\mathrm{a}}\right.$ ), $3.10\left(\mathrm{~d}, 1 \mathrm{H}, J=18.6 \mathrm{~Hz}, \mathrm{H}-10_{\mathrm{b}}\right), 3.13(\mathrm{dd}, 1 \mathrm{H}, J=13.9,6.6 \mathrm{~Hz}$, Phe- $\left.\beta \mathrm{CH}_{\mathrm{b}}\right), 3.59\left(\mathrm{~d}, 1 \mathrm{H}, J=16.9 \mathrm{~Hz}, \mathrm{Gly}-\alpha \mathrm{CH}_{\mathrm{a}}\right), 3.62(\mathrm{~d}, 1 \mathrm{H}, J=1.5 \mathrm{~Hz}$, H-4') $3.73\left(\mathrm{~d}, 1 \mathrm{H}, J=15.9 \mathrm{~Hz}, \mathrm{Gly}-\alpha \mathrm{CH}_{\mathrm{a}}\right), 3.77(\mathrm{~d}, 1 \mathrm{H}, J=15.9 \mathrm{~Hz}$, Gly- $\left.\alpha \mathrm{CH}_{\mathrm{b}}\right), 3.83\left(\mathrm{~d}, 1 \mathrm{H}, J=17.0 \mathrm{~Hz}, \mathrm{Gly}-\alpha \mathrm{CH}_{\mathrm{a}}\right), 3.86(\mathrm{~d}, 1 \mathrm{H}, J=16.9 \mathrm{~Hz}$, Gly- $\alpha \mathrm{CH}_{\mathrm{b}}$ ), $4.02\left(\mathrm{~s}, 3 \mathrm{H}, 4-\mathrm{OCH}_{3}\right), 4.03\left(\mathrm{~d}, 1 \mathrm{H}, J=17.0 \mathrm{~Hz}, \mathrm{Gly}-\alpha \mathrm{CH}_{\mathrm{b}}\right.$ ), $4.16\left(\mathrm{~m}, 1 \mathrm{H}, \mathrm{H}-3^{\prime}\right), 4.30\left(\mathrm{q}, 1 \mathrm{H}, J=6.6 \mathrm{~Hz}, \mathrm{H}-5^{\prime}\right), 4.43(\mathrm{dd}, 1 \mathrm{H}, J=8.4$, $6.6 \mathrm{~Hz}$, Phe- $\alpha \mathrm{CH}$ ), 4.73 (s, 2H, H-14), 5.13 (br s, 1H, H-7), 5.43 (d, 1H, $\left.J=3.9 \mathrm{~Hz}, \mathrm{H}-1^{\prime}\right), 7.16-7.26(\mathrm{~m}, 5 \mathrm{H}$, Phe-aromatic), $7.54(\mathrm{~d}, 1 \mathrm{H}$, $J=8.3 \mathrm{~Hz}, \mathrm{H}-3), 7.80(\mathrm{t}, 1 \mathrm{H}, \mathrm{H}-2), 7.91$ (d, $1 \mathrm{H}, J=7.6 \mathrm{~Hz}, \mathrm{H}-1)$ HL-SI-MS $m / z$ : Calcd for $\mathrm{C}_{42} \mathrm{H}_{48} \mathrm{~N}_{5} \mathrm{O}_{15}\left(\mathrm{M}+\mathrm{H}^{+}\right)$: 862.3147. Found:
862.3147 .

$\mathbf{3}^{\prime}-\boldsymbol{N}$-(Gly-Phe-Gly-Gly)-DXR $\cdot$ HCl (6b) Compound $4 \mathrm{~b}(0.579 \mathrm{~g}$, $1.00 \mathrm{mmol}$ ) was treated with DXR prepared from its hydrochloride $(0.580 \mathrm{~g}, 1.00 \mathrm{mmol})$ and NMM $(0.101 \mathrm{~g}, 1.00 \mathrm{mmol})$, according to the method described for $6 \mathrm{a}$, to afford $6 \mathrm{~b}(0.366 \mathrm{~g}, 40 \%)$. $[\alpha]_{\mathrm{D}}^{24}+206.2^{\circ}$ $(c=0.1, \mathrm{MeOH}) .{ }^{1} \mathrm{H}-\mathrm{NMR}\left(\mathrm{CD}_{3} \mathrm{OD}\right) \delta: 1.28\left(\mathrm{~d}, 3 \mathrm{H}, J=6.6 \mathrm{~Hz}, \mathrm{H}-6^{\prime}\right)$, $1.71\left(\mathrm{dd}, 1 \mathrm{H}, J=12.7,4.6 \mathrm{~Hz}, \mathrm{H}-2_{\mathrm{a}}^{\prime}\right), 2.05(\mathrm{ddd}, 1 \mathrm{H}, J=12.7,12.7,3.4 \mathrm{~Hz}$, $\left.\mathrm{H}-2_{\mathrm{b}}^{\prime}\right), 2.19\left(\mathrm{dd}, 1 \mathrm{H}, J=14.7,5.1 \mathrm{~Hz}, \mathrm{H}-8_{\mathrm{a}}\right), 2.38(\mathrm{~d}, 1 \mathrm{H}, J=14.7 \mathrm{~Hz}$, $\left.\mathrm{H}-8_{\mathrm{b}}\right), 2.94\left(\mathrm{dd}, 1 \mathrm{H}, J=14.0,8.4 \mathrm{~Hz}\right.$, Phe- $\left.\beta \mathrm{CH}_{\mathrm{a}}\right), 3.04$ (d, $1 \mathrm{H}, J=18.5 \mathrm{~Hz}$, $\left.\mathrm{H}-10_{\mathrm{a}}\right), 3.12\left(\mathrm{~d}, 1 \mathrm{H}, J=18.5 \mathrm{~Hz}, \mathrm{H}-10_{\mathrm{b}}\right), 3.12(\mathrm{dd}, 1 \mathrm{H}, J=14.0,6.0 \mathrm{~Hz}$, Phe- $\left.\beta \mathrm{CH}_{\mathrm{b}}\right), 3.56\left(\mathrm{~d}, 1 \mathrm{H}, J=16.1 \mathrm{~Hz}, \mathrm{Gly}-\alpha \mathrm{CH}_{\mathrm{a}}\right), 3.62(\mathrm{~d}, 1 \mathrm{H}, J=1.5 \mathrm{~Hz}$ H-4 $\left.{ }^{\prime}\right), 3.68\left(\mathrm{~d}, 1 \mathrm{H}, J=16.1 \mathrm{~Hz}\right.$, Gly- $\left.\alpha \mathrm{CH}_{\mathrm{a}}\right), 3.69(\mathrm{~d}, 1 \mathrm{H}, J=16.1 \mathrm{~Hz}$, Gly- $\left.\alpha \mathrm{CH}_{\mathrm{b}}\right), 3.79\left(\mathrm{~d}, 1 \mathrm{H}, J=16.6 \mathrm{~Hz}, \mathrm{Gly}-\alpha \mathrm{CH}_{\mathrm{a}}\right), 3.84(\mathrm{~d}, 1 \mathrm{H}, J=16.1 \mathrm{~Hz}$, Gly- $\alpha \mathrm{CH}_{\mathrm{b}}$ ), $3.85\left(\mathrm{~d}, 1 \mathrm{H}, J=16.6 \mathrm{~Hz}, 1 \mathrm{H}, \mathrm{Gly}-\alpha \mathrm{CH}_{\mathrm{b}}\right), 4.03(\mathrm{~s}, 3 \mathrm{H}$, $\left.4-\mathrm{OCH}_{3}\right), 4.14\left(\mathrm{~m}, 1 \mathrm{H}, \mathrm{H}-3^{\prime}\right), 4.28\left(\mathrm{q}, 1 \mathrm{H}, J=6.6 \mathrm{~Hz}, \mathrm{H}-5^{\prime}\right), 4.59$ (dd, $1 \mathrm{H}, J=8.4,6.0 \mathrm{~Hz}$, Phe- $\alpha \mathrm{CH}), 4.70\left(\mathrm{~d}, 1 \mathrm{H}, J=20.8 \mathrm{~Hz}, \mathrm{H}-14_{\mathrm{a}}\right), 4.75(\mathrm{~d}$, $1 \mathrm{H}, J=20.8 \mathrm{~Hz}, \mathrm{H}-14_{\mathrm{b}}$ ), 5.17 (brs, $\left.1 \mathrm{H}, \mathrm{H}-7\right), 5.44$ (d, $1 \mathrm{H}, J=3.4 \mathrm{~Hz}$, $\left.\mathrm{H}^{-1} \mathrm{1}^{\prime}\right), 7.18-7.28(\mathrm{~m}, 5 \mathrm{H}$, Phe-aromatic), $7.57(\mathrm{~d}, 1 \mathrm{H}, J=8.3 \mathrm{~Hz}, \mathrm{H}-3)$, $7.84(\mathrm{t}, 1 \mathrm{H}, \mathrm{H}-2), 7.97(\mathrm{~d}, 1 \mathrm{H}, J=7.3 \mathrm{~Hz}, \mathrm{H}-1)$. HL-SI-MS $m / z$ : $\mathrm{C}_{42} \mathrm{H}_{48} \mathrm{~N}_{5} \mathrm{O}_{15}\left(\mathrm{M}+\mathrm{H}^{+}\right): 862.3147$. Found: 862.3144 .

$\mathbf{3}^{\prime}-\boldsymbol{N}$-(Gly-Gly-Gly-Gly)-DXR-HCl (6c) Compound $\mathbf{4 c}(0.488 \mathrm{~g}$, $1.00 \mathrm{mmol}$ ) was treated with DXR prepared from its hydrochloride $(0.580 \mathrm{~g}, 1.00 \mathrm{mmol})$ and NMM $(0.101 \mathrm{~g}, 1.00 \mathrm{mmol})$, according to the method described for $\mathbf{6 a}$, to afford $\mathbf{6 c}(0.497 \mathrm{~g}, 62 \%)$. $[\alpha]_{\mathrm{D}}^{24}+239.2^{\circ}$ $(c=0.1, \mathrm{MeOH}) .{ }^{1} \mathrm{H}-\mathrm{NMR}\left(\mathrm{CD}_{3} \mathrm{OD}\right) \delta: 1.29\left(\mathrm{~d}, 3 \mathrm{H}, J=6.4 \mathrm{~Hz}, \mathrm{H}-6^{\prime}\right)$, $1.75\left(\mathrm{dd}, 1 \mathrm{H}, J=12.7,3.9 \mathrm{~Hz}, \mathrm{H}-2_{\mathrm{a}}^{\prime}\right), 2.03(\mathrm{ddd}, 1 \mathrm{H}, J=12.7,12.7,3.4 \mathrm{~Hz}$, $\left.\mathrm{H}-2_{\mathrm{b}}^{\prime}\right), 2.18\left(\mathrm{dd}, 1 \mathrm{H}, J=14.7,3.4 \mathrm{~Hz}, \mathrm{H}-8_{\mathrm{a}}\right), 2.36(\mathrm{~d}, 1 \mathrm{H}, J=14.7 \mathrm{~Hz}$, $\left.\mathrm{H}-8_{\mathrm{b}}\right), 3.04\left(\mathrm{~d}, 1 \mathrm{H}, J=18.6 \mathrm{~Hz}, \mathrm{H}-10_{\mathrm{a}}\right), 3.07\left(\mathrm{~d}, 1 \mathrm{H}, J=18.6 \mathrm{~Hz}, \mathrm{H}-10_{\mathrm{b}}\right.$ ), $3.65\left(\mathrm{~d}, 1 \mathrm{H}, J=1.5 \mathrm{~Hz}, \mathrm{H}-4^{\prime}\right), 3.81\left(\mathrm{~s}, 2 \mathrm{H}, \mathrm{Gly}-\alpha \mathrm{CH}_{2}\right), 3.86(\mathrm{~s}, 2 \mathrm{H}$, Gly- $\alpha \mathrm{CH}_{2}$ ), $3.90\left(\mathrm{~s}, 2 \mathrm{H}\right.$, Gly- $\left.\alpha \mathrm{CH}_{2}\right), 3.98\left(\mathrm{~d}, 1 \mathrm{H}, J=16.6 \mathrm{~Hz}\right.$, Gly- $\left.\alpha \mathrm{CH}_{\mathrm{a}}\right)$, $4.03\left(\mathrm{~d}, 1 \mathrm{H}, J=16.6 \mathrm{~Hz}, \mathrm{Gly}-\alpha \mathrm{CH}_{\mathrm{b}}\right), 4.04\left(\mathrm{~s}, 3 \mathrm{H}, 4-\mathrm{OCH}_{3}\right), 4.16(\mathrm{~m}$, $\left.1 \mathrm{H}, \mathrm{H}-3^{\prime}\right), 4.28$ (q, $\left.1 \mathrm{H}, J=6.4 \mathrm{~Hz}, \mathrm{H}-5^{\prime}\right), 4.74\left(\mathrm{~d}, 1 \mathrm{H}, J=21.0 \mathrm{~Hz}, \mathrm{H}-14_{\mathrm{a}}\right.$ ), $4.79\left(\mathrm{~d}, 1 \mathrm{H}, J=21.0 \mathrm{~Hz}, \mathrm{H}-14_{\mathrm{b}}\right), 5.09(\mathrm{br} \mathrm{s}, 1 \mathrm{H}, \mathrm{H}-7), 5.43(\mathrm{~d}, 1 \mathrm{H}$, $\left.J=3.4 \mathrm{~Hz}, \mathrm{H}-1^{\prime}\right), 7.55(\mathrm{~d}, 1 \mathrm{H}, J=8.3 \mathrm{~Hz}, \mathrm{H}-3), 7.83(\mathrm{t}, 1 \mathrm{H}, \mathrm{H}-2), 7.87$ (d, $1 \mathrm{H}, J=7.3 \mathrm{~Hz}, \mathrm{H}-1)$. HL-SI-MS $m / z$ : Calcd for $\mathrm{C}_{35} \mathrm{H}_{42} \mathrm{~N}_{5} \mathrm{O}_{15}$ $\left(\mathrm{M}+\mathrm{H}^{+}\right): 772.2678$. Found: 772.2674.

Synthesis of CMPul (8) Chloroacetic acid (30.0 g) was added to a solution of $7(10.0 \mathrm{~g})$ (molecular weight, $150 \mathrm{kDa}$, Hayashibara) in $6 \mathrm{~N}$ $\mathrm{NaOH}(100 \mathrm{ml})$ at $70^{\circ} \mathrm{C}$, and the mixtutre was stirred for $2 \mathrm{~h}$. When the reaction was complete, the solution was adjusted to $\mathrm{pH} 7.0$ with $\mathrm{AcOH}$ at $20^{\circ} \mathrm{C}$. The solution was poured into $\mathrm{MeOH}(1000 \mathrm{ml})$ and the whole was centrifuged. The precipitate, dissolved in deionized $\mathrm{H}_{2} \mathrm{O}(100 \mathrm{ml})$, was dialyzed using membrane tubing (molecular weight cut-off, $12-14 \mathrm{kDa}$, Spectrum) against deionized $\mathrm{H}_{2} \mathrm{O}$ for $2 \mathrm{~d}$ and lyophilized to give 8 as the sodium salt $(8.90 \mathrm{~g})$.

Measurement of Degree of Substitution of CM Groups Compound 8 was dissolved in $\mathrm{H}_{2} \mathrm{O}$, and chromatography of the solution on a column of cation exchange resin (AG 50W-X8, $\mathrm{H}^{+}$form, BIO-RAD) followed by lyophilization gave 8 as a free form. The compound ( $s \mathrm{mg}$ ) was dissolved in $0.1 \mathrm{~N} \mathrm{NaOH}(10 \mathrm{ml})$ and titrated with $0.1 \mathrm{~N} \mathrm{HCl}(t \mathrm{ml})$ using phenolphthalein solution as an indicator. The degree of substitution $(D S)$ of $\mathrm{CM}$ groups was determined from the following equation.

$$
D S=16.2 \times(10-t) /[s-5.8 \times(10-t)]
$$

Synthesis of CMPul-Gly-Gly-Phe-Gly-DXR (9a) A solution of 6a $(220 \mathrm{mg})$ in $\mathrm{DMF}-\mathrm{H}_{2} \mathrm{O}(1: 1)(10 \mathrm{ml})$ was added to a solution of the sodium salt of $8(1.00 \mathrm{~g})$ in DMF- $\mathrm{H}_{2} \mathrm{O}(1: 1)(30 \mathrm{ml})$. EEDQ $(1.00 \mathrm{~g})$ was added to the mixture and the whole was stirred for $2 \mathrm{~h}$. Undissolved compound was removed by centrifugation, and the supernatant was poured into ethanol $(100 \mathrm{ml})$. The precipitate was dissolved in deionized $\mathrm{H}_{2} \mathrm{O}(30 \mathrm{ml})$ and dialyzed using membrane tubing (molecular weight cut-off $12-14 \mathrm{kDa}$, Spectrum) against deionized $\mathrm{H}_{2} \mathrm{O}$ for $2 \mathrm{~d}$. The solution was passed through a cation exchange resin column (AG $50 \mathrm{~W}-\mathrm{X} 8, \mathrm{Na}^{+}$form), dialyzed against deionized $\mathrm{H}_{2} \mathrm{O}$ for $2 \mathrm{~d}$, and lyophilized to afford $9 \mathbf{a}(0.93 \mathrm{~g})$. Other conjugates $(\mathbf{9 b}-\mathbf{d})$ were prepared via the same procedure.

HPLC of 9a Compound 9a in $0.1 \mathrm{M} \mathrm{NaCl}$ was applied to a column of TSKgel G4000PW $\mathrm{XL}_{\mathrm{L}}(300 \mathrm{~mm} \times 7.8 \mathrm{~mm}$ i.d., Tosoh) and developed with $0.1 \mathrm{M} \mathrm{NaCl}$ at a flow rate of $0.8 \mathrm{ml} / \mathrm{min}$. The system was operated at $40^{\circ} \mathrm{C}$. Detection was performed with a Hitachi L-3300 RI monitor and with a Hitachi L-4200 UV-VIS detector at $480 \mathrm{~nm}$.

In Vitro Drug Release in PBS One $\mathrm{ml}$ of the sample was mixed with $1 \mathrm{ml}$ of $1 \mathrm{M} \mathrm{Na} \mathrm{CO}_{3} / \mathrm{NaHCO}_{3}(\mathrm{pH} \mathrm{9.8)}$ and extracted with $2.5 \mathrm{ml}$ of $\mathrm{CHCl}_{3}-\mathrm{MeOH}(3: 1)$. The organic layer was evaporated and the residue 
was dissolved in the following eluent $(200 \mu \mathrm{l})$. A $20 \mu 1$ aliquot was injected onto a column of Inertsil octadecyl silica (ODS) $(150 \mathrm{~mm} \times 4.6 \mathrm{~mm}$ i.d., GL Sciences Inc.) and eluted with $0.035 \mathrm{M} \mathrm{HCOOH} / \mathrm{HCOONH}_{4}(\mathrm{pH}$ $3.0)-\mathrm{MeOH}(45: 55)$ at a flow rate of $1.0 \mathrm{ml} / \mathrm{min}$. The system was operated at $40{ }^{\circ} \mathrm{C}$. Detection was performed with a Shimadzu RF- 535 fluorescence monitor with excitation at $480 \mathrm{~nm}$ and emission at $590 \mathrm{~nm}$.

Enzymes A mixture of rat liver lysosomal enzymes was prepared according to the method of Trouet. ${ }^{17)}$ The activity of the thiol enzyme in lysosomal enzymes was determined by using Z-Arg-Arg-MCA as the substrate according to Barrett and Kirschke. ${ }^{23)}$ Specific activity was $11.8 \mathrm{U} / \mathrm{min}$ per $\mathrm{ml}$ of enzyme stock solution.

In Vitro Digestion by Lysosomal Enzymes Each of 9a-d $(\mathrm{DXR}=$ $1.8 \times 10^{-5} \mathrm{M}$ ) was incubated at $37^{\circ} \mathrm{C}$ in $0.2 \mathrm{M}$ citrate buffer ( $\left.\mathrm{pH} 5.5\right)$, containing EDTA $(1 \mathrm{~mm}), 0.2 \%$ Triton $\mathrm{X}-100$ and reduced glutathione $(5 \mathrm{~mm})$, with the enzyme solution $\left(0.6 \mathrm{ml} \mathrm{ml}^{-1}\right)$. At various time intervals, $0.1 \mathrm{ml}$ of the incubation mixture was placed in a propylene tube and $\mathrm{MeOH}$ solution $(0.1 \mathrm{ml})$ containing DNR $\left(1.9 \times 10^{-6} \mathrm{M}\right)$ was added as an internal standard. One $\mathrm{ml}$ of $\mathrm{H}_{2} \mathrm{O}, 1 \mathrm{M} \mathrm{Na}_{2} \mathrm{CO}_{3} / \mathrm{NaHCO}_{3}$ (pH 9.8) $(0.1 \mathrm{ml})$ and $\mathrm{CHCl}_{3}-\mathrm{MeOH}(3: 1)(2.5 \mathrm{ml})$ were added and mixed. The organic layer was evaporated and free DXR was determined by HPLC using the method described above.

In Vivo Antitumor Effect Walker carcinosarcoma 256 was inoculated i.m. into female Wistar rats, 6 weeks old, at $1 \times 10^{7}$ cells per rat. CMPul-DXR conjugates and DXR were dissolved in isotonic saline and administered once i.v. at $3 \mathrm{~d}$ after inoculation of the tumor. Four days after the drug injection, the excised tumor weight of each treated group was compared with that of the control group.

\section{References and Notes}

1) Present address: a) Discovery Research Laboratories 1, Shionogi \& Co., Ltd., Sagisu, Fukushima-ku, Osaka 553, Japan; b) Pharmacological Research Laboratory, Tanabe Seiyaku Co., Ltd., Kawagishi, Toda-shi, Saitama 335, Japan; c) Development Research Laboratories, Daiichi Pharmaceutical Co., Ltd., Kitakasai, Edogawa-ku, Tokyo 134, Japan.

2) Trouet A., Masquelier M., Baurain R., Deprez-De Campeneere, D., Proc. Natl. Acad. Sci. U.S.A., 79, 626-629 (1982).

3) Trail P. A., Willner D., Lasch S. J., Henderson A. J., Hofstead S., Casazza A. M., Firestone R. A., Hellström I., Hellstöm K. E.,
Science, 261, 212-215 (1993).

4) Duncan R., Hume I. C., Kopeckova P., Ulbrich K., Strohalm J., Kopecek J., J. Controlled Release, 10, 51-63 (1989).

5) Hirano T., Ohashi S., Morimoto S., Tsuda K., Kobayashi T., Tsukagoshi S., Makromol. Chem., 187, 2815-2824 (1986).

6) Zunino F., Pratesi G., Micheloni A., J. Controlled Release, 10 , $65-73(1989)$.

7) Hoes C. J. T., Grootoonk J., Duncan R., Hume I. C., Bhakoo M., Bouma J. M. W., Feijen J., J. Controlled Release, 23, 37-54 (1993).

8) Cera C., Palumbo M., Stefanelli S., Rassu M., Palù G., Anti-Cancer Drug Design, 7, 143-151 (1992).

9) Ueda Y., Munechika K., Kikukawa A., Kanoh Y., Yamanouchi K., Yokoyama K., Chem. Pharm. Bull., 37, 1639-1641 (1989).

10) Hurwitz E., Wilchek M., Pitha J., J. Appli. Biochem., 2, 25-35 (1980).

11) Kajiki M., Yano T., Gonsho A., Kawaguchi T., Okuno S., Inoue K., Drug Delivery System, 8, 263 -267 (1993).

12) Nakamura S., Yuki Gosei Kagaku Kyokai Shi, 42, 584-588 (1984).

13) Takakura Y., Fujita T., Hashida M., Sezaki H., Pharm. Res., 7, 339-346 (1990)

14) Masquelier M., Baurain R., Trouet A., J. Med. Chem., 23, 1166-1170 (1980)

15) Menozzi M., Valentini L., Vannini E., Arcamone F., J. Pharm. Sci., 73, 766-770 (1984).

16) Ulbrich K., Konak C., Tuzar Z., Kopecek J., Makromol. Chem., 188, 1261-1272 (1987).

17) Trouet A., Methods Enzymol., 31, 323-329 (1974).

18) Yokoyama M., Miyauchi M., Yamada N., Okano T., Sakurai Y., Kataoka K., Inoue S., Cancer Res., 50, $1693-1700$ (1990).

19) Tokes Z. A., Rogers K. E., Rembaum A., Proc. Natl. Acad. Sci. U.S.A., 79, 2026-2030 (1982).

20) Ross, W. E., Glaubiger, D. L., Kohn, K, W., Biochem. Biophys. Acta, 519, 23-30 (1978).

21) Zervas L., Theodoropoulos D. M., J. Am. Chem. Soc., 78 , $1359-1363$ (1956)

22) Yamamoto T., Izumiya N., Arch. Biochem. Biophys., 120, 497-502 (1967).

23) Barrett A. J., Kirschke H., Methods Enzymol., 80, 535-561 (1981). 